\title{
17. THE FORMATION OF PLIOCENE MEDITERRANEAN SAPROPELS: CONSTRAINTS FROM HIGH-RESOLUTION MAJOR AND MINOR ELEMENT STUDIES ${ }^{1}$
}

\author{
R. Wehausen ${ }^{2}$ and H.-J. Brumsack ${ }^{2}$
}

\begin{abstract}
Two Pliocene Mediterranean sediment cores from Sites 964 (Pisano Plateau, Ionian Basin) and 967 (lower northern slope of Eratosthenes Seamount, south of Cyprus), which comprise a total of 428 samples, have been analyzed for major and minor elements ( $\mathrm{Si}, \mathrm{Ti}, \mathrm{Al}, \mathrm{Fe}, \mathrm{Mg}, \mathrm{Ca}, \mathrm{K}, \mathrm{Ba}, \mathrm{Cr}, \mathrm{Ni}, \mathrm{V}, \mathrm{Zn}$, and $\mathrm{Zr}$ ) by X-ray fluorescence analysis at a depth resolution of $3-4 \mathrm{~cm}$. Core 160-964C-9H comprises five sapropels with up to $9.7 \%$ total organic carbon (TOC), one 2.5-m-thick turbidite, and a $50-\mathrm{cm}$ segment of a second turbidite, whereas Core 160-967B-9H contains eight sapropels with TOC content of up to $6.7 \%$.

Cyclic variations in carbonate content and detrital-matter composition are evident at both sites. At Site 964 (Pisano Plateau) terrigenous detrital matter chemistry reflects periods of stronger Saharan dust input alternating with fluvial input from the northern borderlands (higher $\mathrm{K} / \mathrm{Al}$ and $\mathrm{Mg} / \mathrm{Al}$ ratios). Cyclicity is not that well expressed at this location because turbidites or other short-term resedimentation processes occur. Site 967 (Eratosthenes Seamount) sediments are strongly influenced by discharge from the Nile River during humid periods (low $\mathrm{K} / \mathrm{Al}$ and $\mathrm{Mg} / \mathrm{Al}$ ratios).

At Site 967 sapropels are occurring only during periods of enhanced Nile discharge and the corresponding lower Si/Al, Ti/ $\mathrm{Al}, \mathrm{Mg} / \mathrm{Al}, \mathrm{K} / \mathrm{Al}$, and $\mathrm{Zr} / \mathrm{Al}$ ratios. Accumulation rates of carbonate and terrigenous detrital matter were $30 \%$ lower during such episodes because of the reduction in eolian input, carbonate production, and/or carbonate dissolution. Ba enrichments, which are not only seen in the sapropels, but also very periodically in every K/Al minimum, document the triggering effect of enhanced bioproductivity on sapropel formation. As calculated from excess Ba concentrations, productivity increased by up to a factor of five during time intervals of intensified Nile runoff. Fluviatile discharge seems to be responsible for an enhanced input of nutrients and suspended matter containing low $\mathrm{Mg} / \mathrm{Al}$ and $\mathrm{K} / \mathrm{Al}$ ratios.

Based on organic-carbon concentrations, episodes of sapropel formation did last at least from 1000 to $4000 \mathrm{yr}$ at Site 964 and from 2000 to $6000 \mathrm{yr}$ at Site 967. Periods of enhanced bioproductivity, as defined by Ba enrichments, did last from 8000 to $12,000 \mathrm{yr}$ at Site 967. Episodes of high river discharge and corresponding nutrient input, as well as conditions of sapropel formation, seem to have lasted longer in the eastern part of the Eastern Mediterranean (Site 967) as compared to the Pisano Plateau (Site 964).
\end{abstract}

\section{INTRODUCTION}

Pliocene to Holocene Mediterranean sediments contain numerous dark colored layers, termed sapropels, which are characterized by high total organic carbon (TOC $\geq 2 \%$ ), $\mathrm{S}$, and Fe content and significant enrichments in various trace elements (Calvert, 1983; Pruysers et al., 1991; Thomson et al., 1995; Nijenhuis et al., Chap. 16, this volume). Different approaches have been made to elucidate the paleoceanographic scenario that led to their formation.

The occurrence of sapropels is of cyclic nature and seems to correspond closely with minima in the precessional index when perihelion occurred in the northern hemisphere summer (Rossignol-Strick, 1983, 1985; Prell and Kutzbach, 1987; Hilgen, 1991). RossignolStrick (1983) demonstrated that the temporal distribution of the Eastern Mediterranean sapropels correlates with maximum potential strength of the African monsoon, a function of orbital precession, which would have resulted in maximum discharge from the Nile River. Rohling and Hilgen (1991) postulated that increased precipitation along the northern borderlands of the Eastern Mediterranean, because of increased activity of Mediterranean summer depressions, could have been an additional precession-related factor for reduced salinities at sea surface during sapropel formation. By studying the $\delta^{18} \mathrm{O}$ signatures of planktonic foraminifers, it could be shown that surfacewater salinities must have been lower during times of sapropel for-

${ }^{1}$ Robertson, A.H.F., Emeis, K.-C., Richter, C., and Camerlenghi, A. (Eds.), 1998. Proc. ODP, Sci. Results, 160: College Station, TX (Ocean Drilling Program).

${ }^{2}$ Institute of Chemistry and Biology of the Marine Environment (ICBM), Carl von Ossietzky-University Oldenburg, P.O. Box 2503, D-26111 Oldenburg, Federal Republic of Germany.h.brumsack@geo.icbm.uni-oldenburg.de mation (Williams and Thunell, 1979; Vergnaud-Grazzini et al., 1986).

Carbonate cycles found in Pliocene to Holocene Mediterranean sediments have been well examined by use of micropaleontological (De Visser et al., 1989; Howell et al., 1990) and magnetostratigraphical (Langereis and Hilgen, 1991; Hilgen, 1991) as well as geochemical (Van der Weijden, 1993; Van Os et al., 1994) methods. The consensus is that carbonate cycles, including intercalated sapropels, correspond closely with minima in the precessional index (e.g. Rossignol-Strick, 1983; Prell and Kutzbach, 1987; Hilgen, 1991; Lourens et al., 1992).

Only a few studies exist that deal with sources and distribution of terrigenous detrital matter in the Mediterranean Sea sediments. Investigations by Venkatarathnam and Ryan (1971) and Dominik and Stoffers (1978) are based on clay mineralogical studies of surfacesediment cores. Foucault and Mélières (1995) analyzed the mineralogy of cyclic sediments from the Narbone Formation in Sicily. They found varying amounts of eolian and fluvially derived minerals, which, according to their interpretation, were controlled by alternation of humid and dry periods on both the northern and southern borderlands of the Western Mediterranean.

In this paper, high-resolution geochemical studies of Pliocene sedimentary sequences from Ocean Drilling Program (ODP) Sites 964 and 967 in the Eastern Mediterranean are presented. This is the first attempt to investigate longer sedimentary sequences from the Eastern Mediterranean that contain several sapropels by high-resolution major- and minor-element geochemistry. The basic idea behind such an approach is that any change in paleoenvironmental or climatic conditions should be reflected in major- and minor-element abundances. In particular, the question will be addressed, if cyclic chemi- 
cal changes are not only restricted to sapropel-containing intervals, but are also seen in the homogenous parts of the sedimentary sequences.

\section{MATERIALS AND METHODS Sampling Location and Biostratigraphy}

ODP Site 964 (Fig. 1) is located in 3670-m water depth in the Ionian Basin at the foot of the Calabrian Ridge on a small bathymetric high, the Pisano Plateau. Site 967 is located south of Cyprus on the lower northern slope of Eratosthenes Seamount in 2560-m water depth.

Samples were taken from Cores $160-964 \mathrm{C}-9 \mathrm{H}$ and $160-967 \mathrm{~B}-9 \mathrm{H}$ at a resolution of 3-4 cm (distance between the tops of the sampling intervals), with each sample including 2 or $1 \mathrm{~cm}$ of sediment, respectively. The Hole 964C core was sampled over its full length $(270$ samples in total). From Hole 967B, 160 samples were taken from the upper $6.4 \mathrm{~m}$ (Sections 1-5).

According to ODP Leg 160 shipboard biostratigraphic studies both cores are of Pliocene age and 2.6-2.8 Ma (Emeis, Robertson, Richter, et al., 1996; see also for further information about stratigraphy and lithology).

\section{Sample Preparation and Analytical Methods}

Before analysis, the samples were freeze dried and then ground and homogenized in an agate ball mill. For X-ray fluorescence analysis (XRF), $600 \mathrm{mg}$ of the sample powder were mixed with $3600 \mathrm{mg}$ lithium tetraborate $\left(\mathrm{Li}_{2} \mathrm{~B}_{4} \mathrm{O}_{7}\right.$, Spektromelt), preoxidized at $500^{\circ} \mathrm{C}$ with $\mathrm{NH}_{4} \mathrm{NO}_{3}$, and fused to glass beads. The beads were analyzed by a Philips PW 2400 X-ray spectrometer. Analytical precision, as checked by parallel analysis of one international (GSR-6) and several in-house standards, was better than $1 \%$ for major (except for $\mathrm{Na}, 2 \%$ ) and better than $3 \%$ for the minor elements.

TOC content of sapropel samples were determined by coulometric titration following combustion with a Ströhlein instrument after removal of the carbonates with hydrochloric acid (analytical precision was better than $4 \%$ for sapropels and better than $8 \%$ for samples with TOC $<2 \%$ ).

\section{RESULTS AND DISCUSSION}

\section{Bulk Chemistry}

The sediments from both sites investigated may be regarded as marls or calcareous marls with mean $\mathrm{CaCO}_{3}$ content (calculated from $\mathrm{CaO}$ ) of $62 \%$ for Site 964 and $51 \%$ for Site 967 (Table 1). In a ternary plot (Fig. 2), which shows the relative proportions of $\mathrm{SiO}_{2}$ (representing quartz or opaline silica), $\mathrm{Al}_{2} \mathrm{O}_{3}$ (representing clay minerals), and $\mathrm{CaO}$ (representing carbonate), the sediments can be described as mixtures of biogenous carbonate with an aluminosilicate component that is similar in composition to "average shale" (Wedepohl, 1971). Sediments from Site 967 (Eratosthenes Seamount) display slightly higher $\mathrm{Al}_{2} \mathrm{O}_{3}$ contents than those from Site 964 (Ionian Basin), which may indicate a slightly different clay mineralogy. Some specific intervals from Site 964, which are described as "normally graded sections" (Emeis, Robertson, Richter, et al., 1996), show higher $\mathrm{SiO}_{2}$ content. One of these "events" covers the upper $52 \mathrm{~cm}$ of the core, and a second one is located in the center of the core. These and some other thin layers show huge differences in their chemical composition in comparison to the surrounding sediments. The two large "events" have to be regarded as turbidites. Similar sedimentary features have already been described in earlier studies for this area of the Ionian Sea (Kastens and Cita, 1981; Blechschmidt et al., 1982). Thin intervals

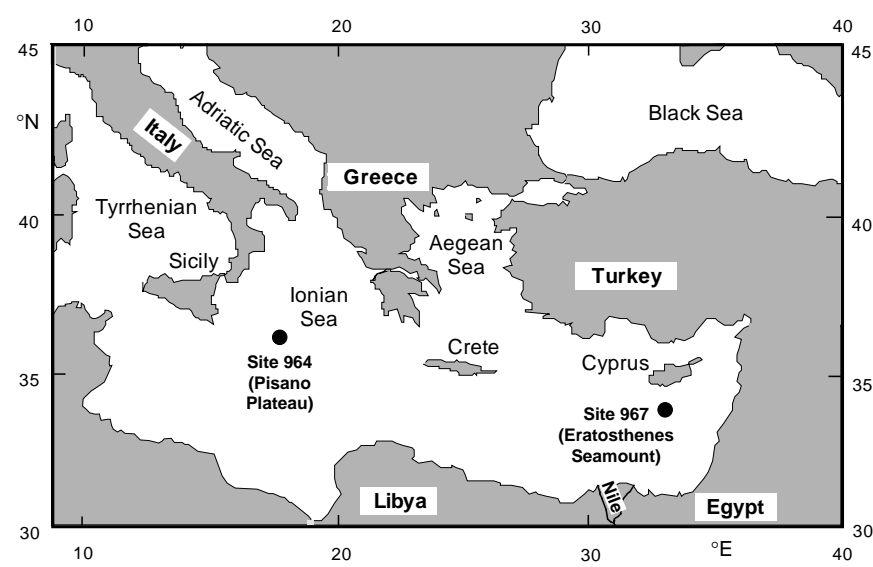

Figure 1. Locations of ODP Sites 964 (Pisano Plateau) and 967 (Eratosthenes Seamount).

rich in Si (quartz) may be caused by particle size fractionation caused by bottom-current-induced resuspension processes (winnowing).

In this contribution, the chemical composition of the sediments is discussed on the basis of element/Al ratios (Table 1). Element/Al ratios are used to compensate for carbonate dilution. Significant differences in the lithogenic sediment fraction of the two sites are evident: $\mathrm{Ti} / \mathrm{Al}$ ratios are higher at Eratosthenes Seamount, whereas $\mathrm{Si} / \mathrm{Al}, \mathrm{Mg}$ / $\mathrm{Al}$, and $\mathrm{K} / \mathrm{Al}$ ratios are higher in the Ionian Basin. Intervals that are referred to as sapropels (Emeis, Robertson, Richter, et al., 1996) are characterized by their typical enrichment in $\mathrm{Fe}$ and specific trace elements, such as $\mathrm{Ba}, \mathrm{Co}, \mathrm{Cr}, \mathrm{Ni}, \mathrm{V}$, and $\mathrm{Zn}$ (Calvert, 1983; Sutherland et al., 1984; Thomson et al., 1995; Nijenhuis et al., Chap. 16, this volume). Maximum values for those elements and higher enrichments relative to average shale (Table 1) are attained in or around sapropel layers. The core from the Ionian Basin (Site 964) contains five individual sapropels with TOC content ranging between $2.2 \%$ and $9.7 \%$. The investigated interval of Core 160-967B-9H (Eratosthenes Seamount) comprises eight sapropels with TOC values between $1.8 \%$ and $6.7 \%$.

\section{Cycles and Events}

The most obvious feature discernible in sediments from Site 964 (Fig. 3) are the turbidites. The one in the center of the core (78-76.5 mbsf) consists of an $\sim 50$-cm-thick basal layer and an overlying $\sim 2-$ $\mathrm{m}$-thick homogenous interval. The basal part is characterized by a higher content of elements that are enriched in minerals of the silt or sand fraction and in heavy minerals, e.g. Si, Ti, $\mathrm{Mg}, \mathrm{Ca}, \mathrm{Ba}$, and $\mathrm{Zr}$. The upper homogenous part of the turbidite displays a high content of $\mathrm{Al}$ (clay fraction). The chemical composition of these sedimentary "events" can easily be explained by a particle sorting effect. $\mathrm{Cr}$ and $\mathrm{V}$ are not enriched in either the upper or the lower parts of the turbidite. Therefore, these elements must be evenly distributed over the different particle-size fractions. The basal layer of a second turbidite, which shows the same chemical characteristics as mentioned above, is present at the top of the core (72 mbsf).

In the lower part of Core 160-964C-9H variations in $\mathrm{Si} / \mathrm{Al}, \mathrm{Ti} / \mathrm{Al}$, $\mathrm{Mg} / \mathrm{Al}, \mathrm{Ca} / \mathrm{Al}, \mathrm{Cr} / \mathrm{Al}$, and $\mathrm{Zr} / \mathrm{Al}$ ratios display a distinct cyclicity (Figs. 3, 4). The Ti/Al and $\mathrm{Zr} / \mathrm{Al}$ profiles are mirror images of $\mathrm{Mg} / \mathrm{Al}$, $\mathrm{Ca} / \mathrm{Al}$, and $\mathrm{Cr} / \mathrm{Al}$. In the upper part of the core this cyclicity is less evident, as it seems to be disrupted by short-term changes in sedimentation. $\mathrm{Ca} / \mathrm{Al}$ ratios as well as $\mathrm{CaCO}_{3}$ content (calculated from $\mathrm{CaO}$ values) show a large variability. In contrast to the relatively smooth, cyclic changes in $\mathrm{CaCO}_{3}$ contents, as displayed between 78.1 and 79.5 mbsf (Fig. 3), the $\mathrm{CaCO}_{3}$ content decreases drastically by as 
Table 1. Element abundance and element/Al ratio of Core 160-964C-9H (turbidites excluded) and Core 160-967B-9H, Sections 1-5.

\begin{tabular}{|c|c|c|c|c|c|c|c|}
\hline \multirow{2}{*}{$\begin{array}{l}\text { Elemental } \\
\text { abundance }\end{array}$} & \multicolumn{3}{|c|}{ Site 964 (Ionian Basin) } & \multicolumn{3}{|c|}{ Site 967 (Eratosthenes Seamount) } & \multirow{2}{*}{$\begin{array}{c}\text { Average } \\
\text { shale }\end{array}$} \\
\hline & Average & Minimum & Maximum & Average & Minimum & Maximum & \\
\hline $\mathrm{SiO}_{2}(\%)$ & 19.09 & 10.03 & 41.99 & 22.92 & 14.72 & 31.40 & 58.00 \\
\hline $\mathrm{TiO}_{2}(\%)$ & 0.325 & 0.172 & 0.647 & 0.515 & 0.309 & 0.736 & 0.780 \\
\hline $\mathrm{Al}_{2} \mathrm{O}_{3}(\%)$ & 6.11 & 2.77 & 12.78 & 8.53 & 5.74 & 11.00 & 16.80 \\
\hline $\mathrm{Fe}_{2} \mathrm{O}_{3}(\%)$ & 2.81 & 0.97 & 12.59 & 4.27 & 2.86 & 12.90 & 6.90 \\
\hline $\mathrm{MgO}(\%)$ & 1.97 & 1.17 & 5.56 & 1.74 & 1.23 & 2.33 & 2.60 \\
\hline $\mathrm{CaO}(\%)$ & 34.61 & 8.27 & 44.22 & 28.72 & 16.96 & 36.89 & 2.30 \\
\hline $\mathrm{K}_{2} \mathrm{O}(\%)$ & 1.24 & 0.70 & 2.66 & 1.18 & 0.74 & 1.59 & 3.40 \\
\hline $\mathrm{Ba}(\mu \mathrm{g} / \mathrm{g})$ & 179 & 55 & 2519 & 270 & 80 & 1060 & 650 \\
\hline $\mathrm{Cr}(\mu \mathrm{g} / \mathrm{g})$ & 58 & 21 & 281 & 59 & 39 & 103 & 90 \\
\hline $\mathrm{Ni}(\mu \mathrm{g} / \mathrm{g})$ & 55 & 2 & 649 & 63 & 25 & 394 & 68 \\
\hline $\mathrm{V}(\mu \mathrm{g} / \mathrm{g})$ & 74 & 22 & 841 & 105 & 51 & 568 & 130 \\
\hline $\mathrm{Zn}(\mu \mathrm{g} / \mathrm{g})$ & 38 & 14 & 179 & 52 & 34 & 99 & 95 \\
\hline $\mathrm{Zr}(\mu \mathrm{g} / \mathrm{g})$ & 73 & 33 & 227 & 95 & 46 & 152 & 200 \\
\hline $\mathrm{CaCO}_{3}(\%)^{*}$ & 61.8 & 14.7 & 78.9 & 51.3 & 30.3 & 65.8 & 4.1 \\
\hline \multicolumn{8}{|l|}{ Element/Al ratio } \\
\hline $\mathrm{Si} / \mathrm{Al}$ & 2.75 & 2.46 & 5.83 & 2.38 & 2.10 & 2.69 & 3.00 \\
\hline $\mathrm{Ti} / \mathrm{Al}$ & 0.060 & 0.051 & 0.115 & 0.068 & 0.056 & 0.084 & 0.053 \\
\hline $\mathrm{Fe} / \mathrm{Al}$ & 0.60 & 0.41 & 2.29 & 0.67 & 0.52 & 2.63 & 0.54 \\
\hline $\mathrm{Mg} / \mathrm{Al}$ & 0.37 & 0.27 & 0.75 & 0.24 & 0.17 & 0.33 & 0.18 \\
\hline $\mathrm{Ca} / \mathrm{Al}$ & 8.55 & 1.07 & 19.17 & 4.66 & 2.63 & 8.25 & 0.18 \\
\hline $\mathrm{K} / \mathrm{Al}$ & 0.32 & 0.30 & 0.41 & 0.22 & 0.17 & 0.26 & 0.32 \\
\hline $\mathrm{Ba} / \mathrm{Al} \times 10^{-4}$ & 54 & 26 & 917 & 61 & 19 & 297 & 73 \\
\hline $\mathrm{Cr} / \mathrm{Al} \times 10^{-4}$ & 17 & 10 & 47 & 13 & 10 & 23 & 10 \\
\hline $\mathrm{Ni} / \mathrm{Al} \times 10^{-4}$ & 15 & 1 & 117 & 14 & 5 & 130 & 8 \\
\hline $\mathrm{V} / \mathrm{Al} \times 10^{-4}$ & 22 & 14 & 152 & 24 & 12 & 148 & 15 \\
\hline $\mathrm{Zn} / \mathrm{Al} \times 10^{-4}$ & 11 & 7 & 34 & 12 & 8 & 24 & 11 \\
\hline $\mathrm{Zr} / \mathrm{Al} \times 10^{-4}$ & 23 & 13 & 155 & 21 & 14 & 29 & 22 \\
\hline \multicolumn{8}{|l|}{ Sapropels: } \\
\hline TOC (\%) & & 2.2 & 9.7 & & 1.8 & 6.7 & 0.2 \\
\hline
\end{tabular}

Notes: * = calculated from CaO values. Average shale data set from Wedepohl $(1971,1991)$.

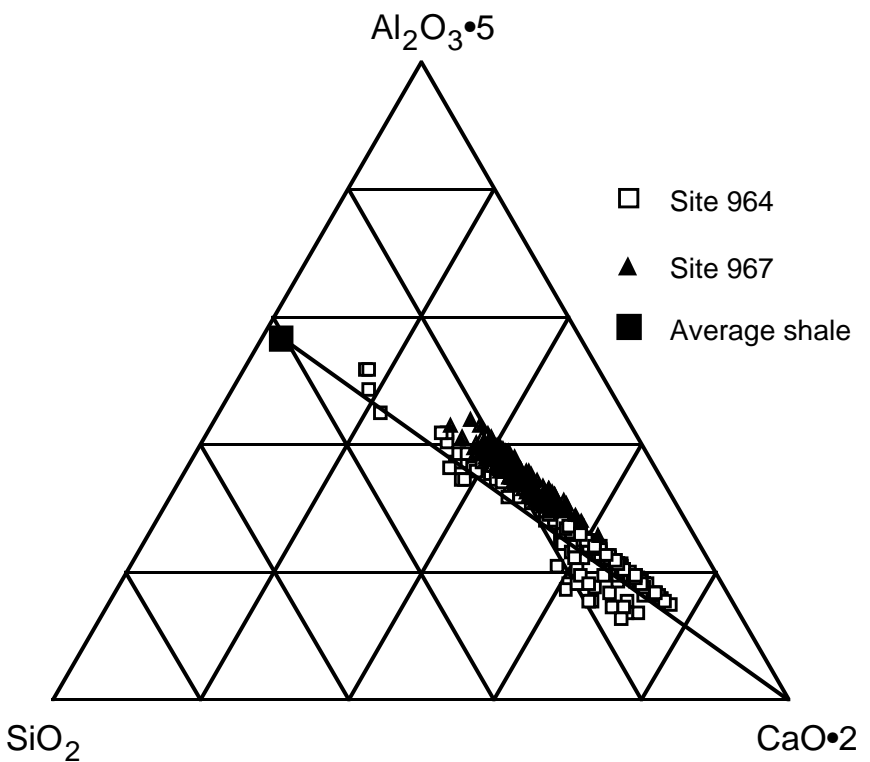

Figure 2. Ternary plot of $\mathrm{SiO}_{2}$ (representing quartz or opaline silica), $\mathrm{Al}_{2} \mathrm{O}_{3}$ (representing clay minerals), and $\mathrm{CaO}$ (representing carbonate). Average shale data point from Wedepohl $(1971,1991)$.

much as $40 \%$ in the sapropels, which can be explained by dissolution of carbonate. The sapropel at 80.6-80.7 mbsf (Fig. 4) also shows a decrease in the $\mathrm{Mg} / \mathrm{Al}$ ratio. By leaching two samples of this site with water and $1 \mathrm{~mol} / \mathrm{L}$ acetic acid, respectively, and analyzing the residues by XRF, we were able to see that Mg is partly present as sea salt and partly bound to carbonate phases, which might dissolve during sapropel formation. However, most of the Mg was still present in the residue after treatment with acetic acid, and a correlation between $\mathrm{Mg}$ and $\mathrm{Ca}$ is not observed. Therefore, the major fraction of the $\mathrm{Mg}$ seems to be fixed in the detrital clay mineral component of terrigenous origin.

Aside from the carbonate cycles, which are presumably resulting from orbital forcing (Hilgen, 1991), rhythmic variations in detritalmatter composition of the sediments should also have been caused by Milankovich-type cycles, because they all seem to have the same frequency pattern. This can be seen in the $\mathrm{Si} / \mathrm{Al}, \mathrm{Ti} / \mathrm{Al}, \mathrm{Mg} / \mathrm{Al}, \mathrm{Ca} / \mathrm{Al}$, $\mathrm{Cr} / \mathrm{Al}$, and $\mathrm{Zr} / \mathrm{Al}$ ratios (Figs. 3, 4). Cyclicity in elemental ratios is often disturbed by other sedimentary features such as those found in the upper part of Core 160-964C-9H. These features are, for example, indicated by "spikes" in the $\mathrm{Si} / \mathrm{Al}, \mathrm{Ti} / \mathrm{Al}, \mathrm{Mg} / \mathrm{Al}$, and $\mathrm{Zr} / \mathrm{Al}$ ratios (Fig. $3)$.

In Core 160-967B-9H from the Eratosthenes Seamount, cyclicity is displayed by all elements of a typical lithogenic origin. Depth profiles of $\mathrm{Si} / \mathrm{Al}, \mathrm{Ti} / \mathrm{Al}, \mathrm{Mg} / \mathrm{Al}, \mathrm{K} / \mathrm{Al}$, and $\mathrm{Zr} / \mathrm{Al}$ ratios all show very similar shapes (Fig. 5). Ca/Al shows a similar pattern as the other elements with the exception of an interval without sapropels (76.8-74.5 mbsf). This implies that the cyclicity of all element/Al ratios is likely caused by earth precessional cycles (see above).

Every minimum in element/Al ratio is marked by an enrichment in $\mathrm{Ba} / \mathrm{Al}$. All sapropel layers are enriched in $\mathrm{Ba}$, but not all $\mathrm{Ba}-$ enriched layers are typical sapropels. Four Ba spikes are discernible in the sapropel-free interval (76.8-74.5 mbsf) that, as far as we can notice by our sampling resolution, do not show significant trace metal enrichments like observed in oxidized ("burned-down") sapropels as described by Thomson et al. (1995). Only very slight enrichments in trace metals and $\mathrm{Fe}$ are apparent in the profiles (Fig.5).

From the chemical profiles (Fig. 5), it seems evident that Baenriched intervals, like those typically encountered in sapropels, were deposited during periods when lithogenic matter with lower $\mathrm{Si} /$ $\mathrm{Al}, \mathrm{Ti} / \mathrm{Al}, \mathrm{Mg} / \mathrm{Al}, \mathrm{K} / \mathrm{Al}$, and $\mathrm{Zr} / \mathrm{Al}$ ratios was introduced into the Eastern Mediterranean.

At the Eratosthenes Seamount location (Site 967), cyclic sedimentary changes are more distinctive, and sapropel formation did take place more regularly than in the Ionian Basin (Site 964). Additionally, sapropels and Ba-enriched layers are more substantial than 




Figure 3. Carbonate content and element/Al ratio of ODP Core 160-964C-9H (Pisano Plateau, Ionian Basin). Gray bars = sapropels; hatched areas = turbidites. 


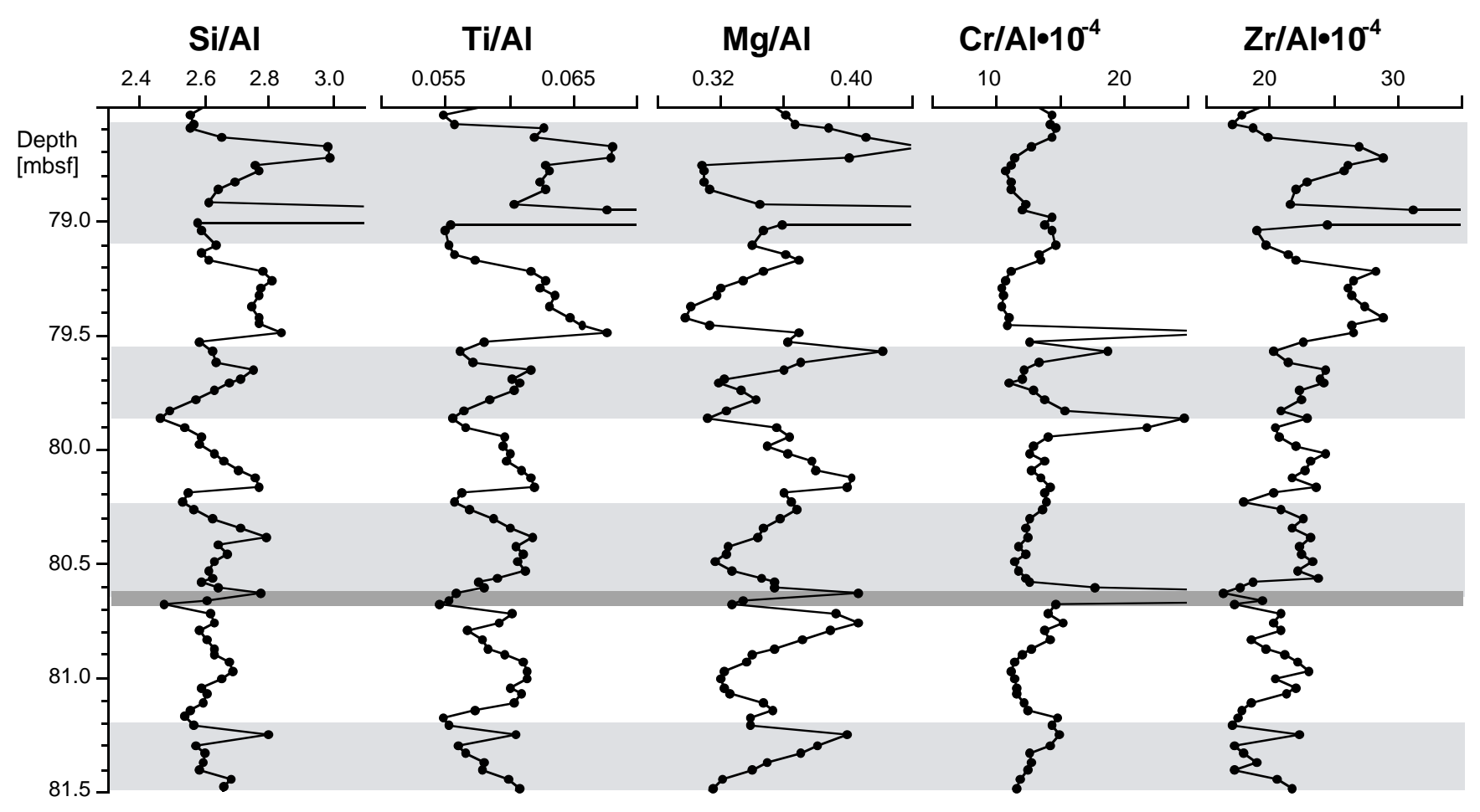

Figure 4. Depth profiles of element/Al ratios of Core 160-964C-9H, Sections 5 through CC. Dark gray bar = sapropel; light gray/white bars = precession cycles .

those encountered at Site 964 . For Site 964 sapropels, it cannot be ruled out whether they occur exactly within certain minima or maxima of detrital element/Al ratios. At Site 967 (Fig. 5), carbonate concentrations do not show the extreme variations as observed at Site 964.

\section{Paleoproductivity}

Ba has for a long time been under discussion as an indicator element for paleoproductivity (Goldberg and Arrhenius, 1958; Dehairs et al., 1980; Schmitz, 1987; Lea and Boyle, 1990; Dymond et al., 1992). Eastern Mediterranean sapropels always show enrichments in Ba (Calvert, 1983; Sutherland et al., 1984; Higgs et al., 1994; Thomson et al., 1995). Van Os et al. (1991) stated that sedimentary barite might undergo diagenetic changes and should, therefore, be used carefully as a paleoproductivity indicator. However, Ba mobilization will only be possible under conditions of severe sulfate depletion (Brumsack and Gieskes, 1983; Brumsack, 1986; Brumsack et al., 1992). Although they could demonstrate that sediments had undergone diagenetic changes, Thomson et al. (1995) found approximately Gaussian-shaped Ba profiles in sediments in and around the most recent sapropel, S1. Our sampling resolution is not high enough to see a Gaussian-shaped Ba distribution, but the Ba peaks seem to be symmetrical (Fig. 5). Therefore, we suggest that $\mathrm{Ba}$ is indeed useful as a paleoproductivity indicator and that productivity increases are evident at Site 967 during those time periods when detrital matter exhibit lows in element/Al-ratios, even when sapropels were not deposited (Fig. 5). In such intervals, enrichments in Fe and trace elements are only very minor, and it is questionable whether there have formerly been real sapropels (TOC $\geq 2 \%$ ) or sapropelic layers (TOC between $0.5 \%$ and $2 \%$ ) that were "burned down" by an oxidation front. At Site 964 we have detected several intervals with enhanced $\mathrm{Ba} / \mathrm{Al}$ ratios (see Fig. 3; 74.5 mbsf and $\sim 79.8$ mbsf), but low organic-carbon content. Since the elements $\mathrm{Fe}, \mathrm{Cr}, \mathrm{Ni}$, and $\mathrm{V}$ are clearly enriched within or above these layers, this might indicate the former occurrence of sapropels, which now have been completely oxidized.
Ba content may be used to estimate paleoproductivity according to an algorithm given by Dymond et al. (1992). For performing such a calculation, the fraction of nonlithogenic $\mathrm{Ba}\left(\mathrm{Ba}_{\text {bio }}\right)$ in the sediments has to be known. This fraction is easily obtained when $\mathrm{Ba}$ and $\mathrm{Al}$ concentrations are known. The biogenic $\mathrm{Ba}$ fraction is calculated according to

$$
\mathrm{Ba}_{\text {bio }}=\mathrm{Ba}_{\text {total }}-\left[\mathrm{Al} \times(\mathrm{Ba} / \mathrm{Al})_{\text {detrit. }}\right] \text {, }
$$

where $(\mathrm{Ba} / \mathrm{Al})_{\text {detrit. }}$ represents the $\mathrm{Ba} / \mathrm{Al}$ ratio of the detrital fraction. For the Eastern Mediterranean Pliocene sediments from Site 967 a minimum $\mathrm{Ba} / \mathrm{Al}$ ratio of 0.0019 has been analyzed for the homogenous, nonsapropel sections, which is identical to the value given by Van Os et al. (1994). The accumulation rate of biologically mediated $\mathrm{Ba}\left(\mathrm{Ba}_{\text {bio-acc. }}\right)$ can be obtained from

$$
\mathrm{Ba}_{\text {bio-acc. }}=\mathrm{Ba}_{\text {bio }}[\mathrm{ppm}] \times \mathrm{MAR} / 10^{6},
$$

where MAR is the mass accumulation rate. The biogenic Ba flux to the seafloor is computed using the following equation of Dymond et al. (1992):

$$
\mathrm{Ba}_{\text {bio }} \text { flux }=\mathrm{Ba}_{\text {bio-acc. }} /(0.209 \times \log \mathrm{MAR}-0.213) .
$$

Finally, the new (or export) production $\left(\mathrm{P}_{\text {new }}\right)$, as defined by Sarnthein et al. (1988), is calculated according to

$$
\mathrm{P}_{\text {new }}=\left\{\left[\left(\mathrm{Ba}_{\text {bio }} \text { flux } \times 0.171 \mathrm{Ba}_{\mathrm{z}}^{2.218} \times \mathrm{z}^{0.476-0.00478 \times \mathrm{Ba}}\right) / 2056\right]^{1.504}\right\},
$$

where $\mathrm{Ba}_{\mathrm{z}}$ is the concentration of dissolved barium in the water depth z. For z, a value of $1700 \mathrm{~m}$ is recommended (Dymond et al., 1992 ), and a value of $11 \mu \mathrm{g} / \mathrm{L}$ dissolved $B$ a has been taken from Bernat et al. (1972). The new production $\left(\mathrm{P}_{\text {new }}\right)$ derived from this equation for the sapropels of Site 967 amounts to values from 26 to 62 


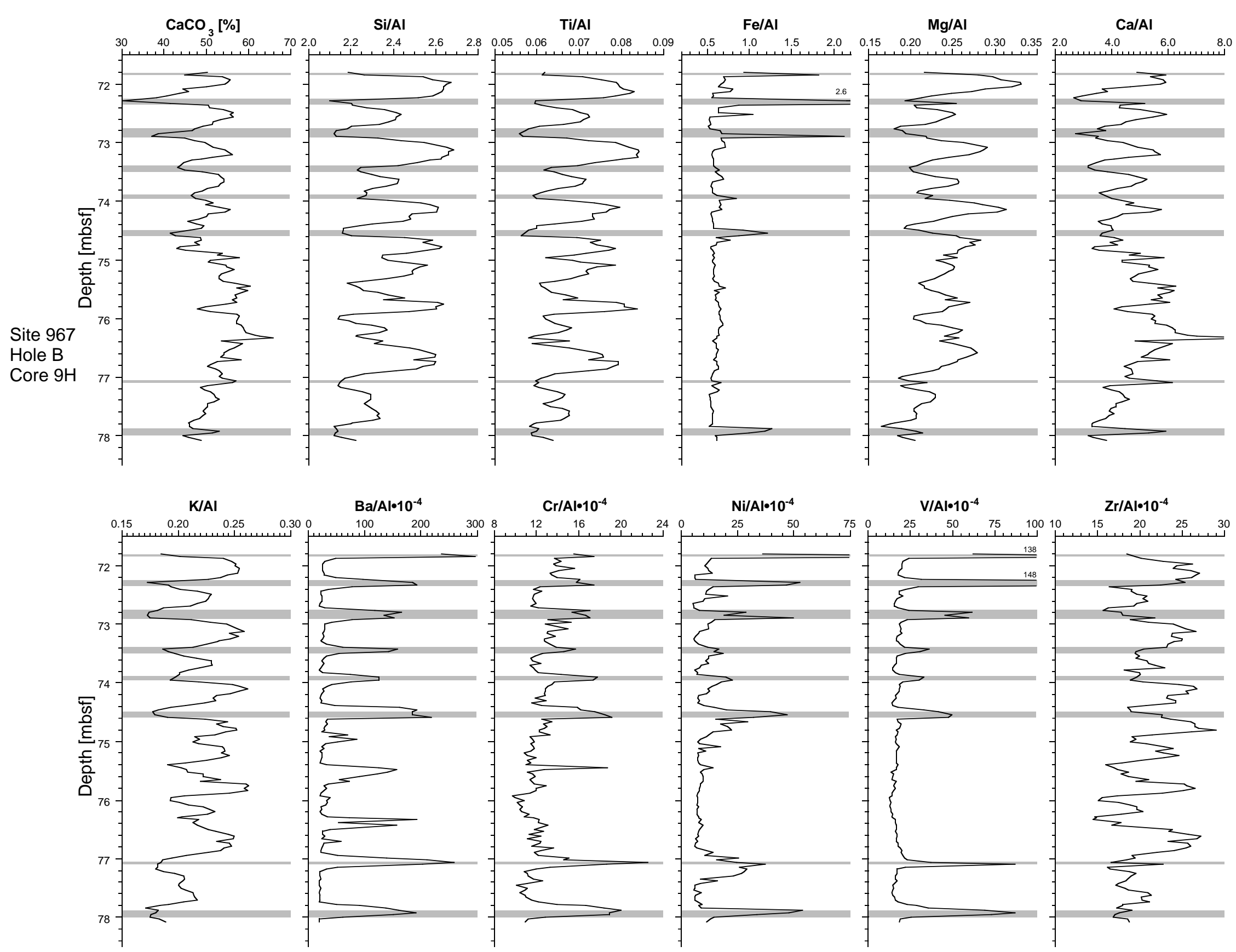

Figure 5. Carbonate content and element/Al ratio of ODP Core 160-967B-9H, Sections 1 through 5 (Eratosthenes Seamount). Gray bars = sapropels. 
$\mathrm{gC} / \mathrm{m}^{2} \cdot \mathrm{yr}$, and for the nonsapropelic, but Ba-enriched layers, to values ranging from 2 to $29 \mathrm{gC} / \mathrm{m}^{2}$.yr. Compared with data given by Béthoux $\left(1989 ; \mathrm{P}_{\text {new }}=12 \mathrm{gC} / \mathrm{m}^{2} \cdot \mathrm{yr}\right)$ or Krom et al. $\left(1992 ; \mathrm{P}_{\text {new }}=\right.$ $16.7 \mathrm{gC} / \mathrm{m}^{2} \cdot \mathrm{yr}$ ) for the modern Eastern Mediterranean, the export production during times of sapropel formation amounts to five times the present value. Time intervals of increased productivity without corresponding sapropel formation are characterized by a new production of up to two or three times the modern values. Unrealistically small values of $2 \mathrm{gC} / \mathrm{m}^{2}$. $\mathrm{yr}$ or less, calculated for the intervals between the Ba spikes, show that the productivity determination using the Dymond et al. (1992) algorithm is not very accurate in our case. Dymond et al. (1992) established and tested their equations on samples from the western Atlantic, equatorial Pacific, and California current.

Howell and Thunell (1992) found, based on organic-carbon accumulation rates, a 10-fold increase in primary productivity for time of sapropel formation. Our calculated productivity values are at least suitable to recognize differences between individual productivity events within one site. New production did not reach such high values during productivity events without the presence of sapropels compared to those intervals where sapropels are present. Furthermore, it must be noted that $\mathrm{K} / \mathrm{Al}$ ratios on average do not show such extreme minima in the nonsapropelic productivity events as they do in the sapropelic ones (Fig. 5).

\section{Origin and Transport Paths of Detrital Matter}

Sediments of the Eratosthenes Seamount are deposited relatively close to the Nile Cone. Therefore, a strong influence of Nile-derived suspended matter can be expected for this location. According to Venkatarathnam and Ryan (1971), Nile suspended matter, which is characterized by high smectite contents, presently is dispersed mainly in the eastern Levantine Basin. It is transported by the easterly directed surface-water currents that form part of a counter-clockwise gyre, whereas the deep parts of the Ionian Basin are fed by deep water and particularly bottom currents from the Aegean and Adriatic Seas, which contain high illite and chlorite contents. These hypotheses are supported by other authors. Dominik and Stoffers (1978), for example, identified high abundances of illite and chlorite in the clay fraction of the Ionian Basin sediments. Adjacent to the Nile Cone, the samples are dominated by smectite. Illite and kaolinite have a minor role with each contributing about $10 \%$ of the clay fraction.

Aside from fluvial sources (e.g., the Nile, rivers entering the Black Sea, the Po, and other rivers of the northern borderlands), there exists an important eolian contribution to the detrital matter that is deposited in the Eastern Mediterranean (Ganor and Mamane, 1982).

The high $\mathrm{K} / \mathrm{Al}$ and $\mathrm{Mg} / \mathrm{Al}$ ratios we observed in the Ionian Basin sediments correspond well with the regionally higher input of illite (K-rich) and chlorite (Mg-rich) by fluvial (Dominik and Stoffers, 1978) or eolian (Tomadin et al., 1984) sources. Levantine Sea sediments, like those from Site 967, are influenced by the Nile River, and therefore contain higher abundances of clay minerals that have lower $\mathrm{K} / \mathrm{Al}$ and $\mathrm{Mg} / \mathrm{Al}$ ratios, like smectite and kaolinite (Venkatarathnam and Ryan, 1971).

During times of sapropel deposition at the Eratosthenes Seamount, $\mathrm{K} / \mathrm{Al}$ and $\mathrm{Mg} / \mathrm{Al}$ ratios were lower (Fig. 5). This could have been caused by an intensification of Nile suspended-matter delivery (Rossignol-Strick, 1983, 1985), a decreasing influence of fluvial or eolian detrital-matter contribution from the northern borderlands, or restricted easterly directed currents, which may carry more illite-rich clay minerals from the west. A plot of Mg/Al vs. K/Al (Site 964 turbidites are excluded) shows a correlation for each of the two sample sets (Fig. 6). This correlation implies that $\mathrm{Mg} / \mathrm{Al}$ and $\mathrm{K} / \mathrm{Al}$ ratios are controlled at both sites by two end members. For Site 967, one end member is represented by a data point for Nile suspended matter as described by Martin and Meybeck (1979), whereas the other end member is possibly an eolian component represented by Saharan dust (Rachold, 1991) or Damascus dust (Cornille et al., 1990). For Site 964, a similar eolian component may be important as one end member, and a component with higher $\mathrm{Mg} / \mathrm{Al}$ and slightly higher $\mathrm{K} / \mathrm{Al}$ ratios, probably fluvial material from the northern borderlands with higher chlorite contents, is the second end member.

The elements $\mathrm{Si}$ (representing quartz) and $\mathrm{Zr}$ (representing the heavy mineral zircon) are enriched in desert sands, because their host minerals are extremely resistant against weathering (Wedepohl, 1967; Matthes, 1993). Quartz has been investigated in eolian dust from southern provenances by several authors (Chester et al.,1977; Ganor and Mamane, 1982; Tomadin et al., 1984). The Element $\mathrm{Zr}$ is enriched in loess, an eolian deposit (Schnetger, 1992), and Saharan dust (Rachold, 1991). The fact that Site 967 sapropels generally exhibit lower $\mathrm{Zr} / \mathrm{Al}$ and $\mathrm{Si} / \mathrm{Al}$ ratios further supports the assumption that the sediments have received lower proportions of eolian dust during time intervals when sapropels were formed. Rhythmic fluctuations in $\mathrm{Si} / \mathrm{Al}$ and $\mathrm{Zr} / \mathrm{Al}$, which are possibly caused by variations in the eolian contribution to sedimentation, have also been found in sediments from Site 964 (Fig. 4).

Further evidence for higher Nile discharge and lower eolian input during times of sapropel formation is given by $\mathrm{Sr}$-isotope investigations. Nonsapropel samples from the Eastern Mediterranean and Saharan dust samples have higher ${ }^{87} \mathrm{Sr} /{ }^{86} \mathrm{Sr}$ ratios than sapropels and Nile sediments, because Nile suspended matter largely originates from the erosion of relatively young Ethiopian volcanics with low ${ }^{87} \mathrm{Sr} /{ }^{86} \mathrm{Sr}$ ratios (Michard et al., 1995; Ströhle et al., 1996). Saharan dust particles, by contrast, are formed by erosion of old Archaean strata with more radiogenic ${ }^{87} \mathrm{Sr} /{ }^{86} \mathrm{Sr}$ ratios. First ${ }^{87} \mathrm{Sr} /{ }^{86} \mathrm{Sr}$ measurements on the noncarbonate fraction of our samples from Site 967 reveal values of 0.7086 and 0.7094 for $\mathrm{K} / \mathrm{Al}$ minima (humid periods) in contrast to 0.7092 and 0.7103 for $\mathrm{K} / \mathrm{Al}$ maxima (arid periods), which correspond with the findings of others (Michard et al., 1995; Ströhle et al., 1996).

\section{Sedimentation and Accumulation Rates}

At Site 964 the Cr/Al ratio profile displays the most regular cyclicity record and is used to determine the sedimentation rate. Assuming a Milankovitch periodicity of 21 k.y. (Fischer and Bottjer, 1991),

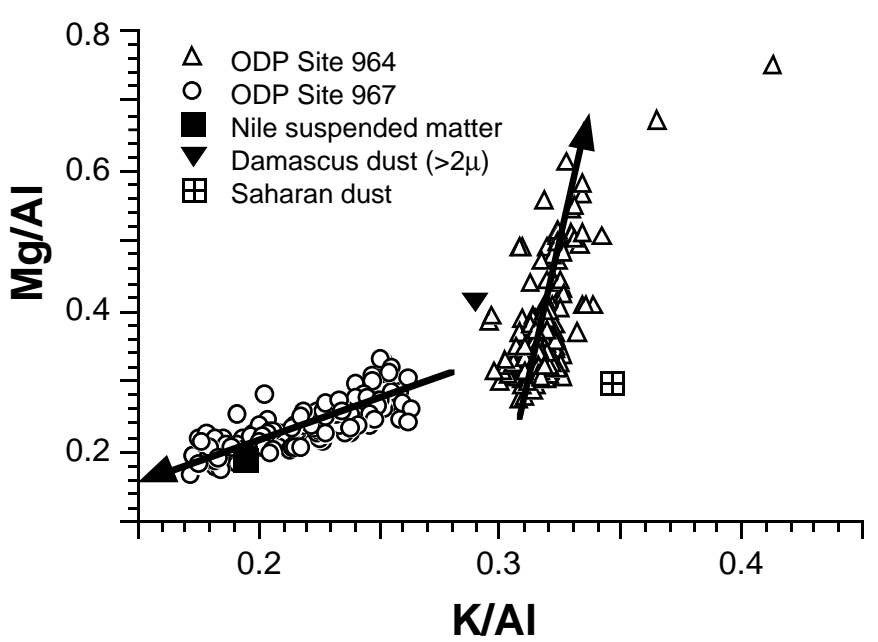

Figure 6. Plot of $\mathrm{Mg} / \mathrm{Al}$ vs. $\mathrm{K} / \mathrm{Al}$ ratios. Arrows indicate changes in sediment composition during times of sapropel formation. Turbidites are excluded from the Site 964 data set. Damascus dust data from Cornille et al. (1990); Saharan dust data from Rachold (1991). 
Figure 7. Calculation of sedimentation rates at Core $160-967 \mathrm{~B}-9 \mathrm{H}$. It is assumed that the K/Al curve represents a 21-k.y. precessional cyclicity. The curve is divided into time slices of $\sim 10.5$ k.y. (based on the assumption that $21 \mathrm{k.y} .=$ one full precessional cycle). Boundaries between these zones of minima and maxima of the $\mathrm{K} / \mathrm{Al}$ curve are the points of inflection.

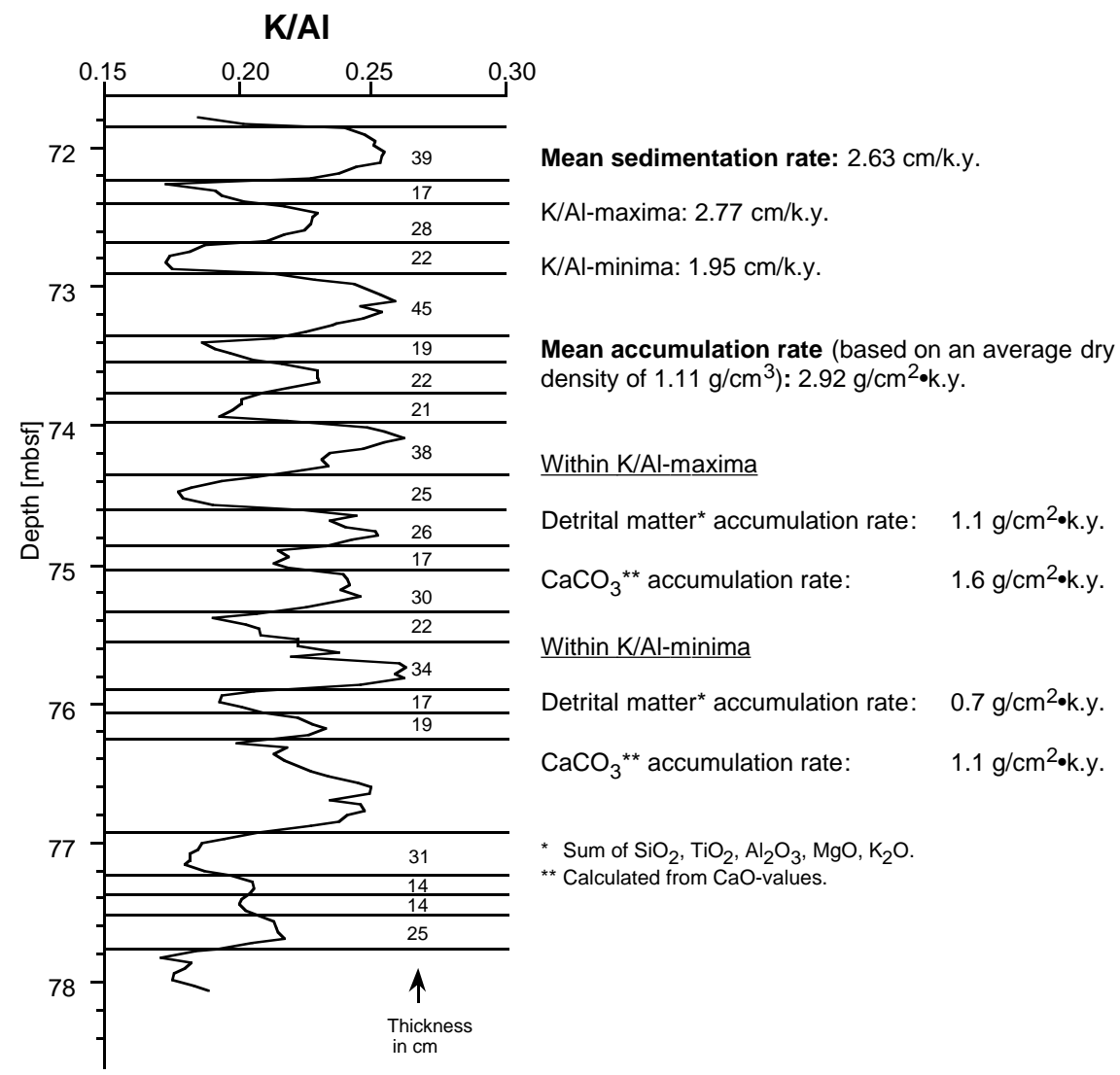

the resulting sedimentation rate equals $2.38 \mathrm{~cm} / \mathrm{k} . \mathrm{y}$. This value seems to be low in comparison to ODP Leg 160 shipboard biostratigraphical studies (Emeis et al., 1996), where a higher value of $2.7 \mathrm{~cm} / \mathrm{k} . \mathrm{y}$. was determined. This high value is possibly caused by enhanced sediment accumulation because of turbidite deposition, which is not considered in our cyclochemostratigraphic approach.

In sediments from Site 967, Si/Al, Ti/Al, Mg/Al, K/Al, and Zr/Al do not display regular sinusoidal curves. The profiles look compressed in the sapropel intervals. One reason for this could be a decrease in the supply of carbonate during sapropel deposition or carbonate dissolution, which would lead to lower sedimentation rates. But, it should be noted that intervals without sapropels do also show an asymmetric pattern (Fig. 5).

With our data set we are able to give an estimate of the total amount of carbonate and terrigenous detrital matter accumulation per time interval. The sedimentary cycles, which are best seen in the K/ $\mathrm{Al}$ record, are divided into minima and maxima. Boundaries between highs and lows are the points of inflection of the K/Al curve (Fig. 7). From the part of the core investigated, the average mass accumulation rate (MAR) is calculated. The mean sedimentation rate, based on a 21 k.y. periodicity of the cycles (Fischer and Bottjer, 1991), is 2.63 $\mathrm{cm} / \mathrm{k} . \mathrm{y}$. For the K/Al maxima and minima, mean sedimentation rates of $2.77 \mathrm{~cm} / \mathrm{k} . y$. and $1.95 \mathrm{~cm} / \mathrm{k} . y$. , respectively, were calculated (Fig. 7). Considering dry bulk densities from ODP Leg 160 shipboard measurements (Emeis, Robertson, Richter, et al., 1996), a mean MAR of $2.92 \mathrm{~g} / \mathrm{cm}^{2} \cdot \mathrm{k} . \mathrm{y}$. is obtained. Furthermore, the accumulation rates of detrital matter and carbonate may be calculated for K/Al minima and maxima respectively (Fig. 7). The overall result of the calculations is that the accumulation of terrigenous detrital matter and carbonate was reduced by $30 \%$ during intervals with low $\mathrm{K} / \mathrm{Al}$ ratios (i.e., during times of sapropel formation).

Mangini and Dominik (1979) determined the sedimentation rates of Eastern Mediterranean sediments by ${ }^{230} \mathrm{Th}$ budget calculations. According to their measurements, sedimentation rates in the sapropels were lower than in the surrounding sediments. Dominik and Stoffers (1978) found a different clay-mineral assemblage in the sapropels as compared to adjacent intervals. We assume that the sedimentation rate decreased because of a lower carbonate productivity and partial dissolution of carbonate, and additionally, by simultaneous and rapid changes in supply of terrigenous detrital matter. According to Van Os et al. (1994), Pliocene and Pleistocene carbonate cycles are caused by variations in productivity. Carbonate production collapsed during high-productivity episodes because of a faster growth of more opportunistic organisms, which probably were more tolerant against rapidly changing oceanographic conditions. Van Os et al. (1994) showed by calculations that the decrease in carbonate could not be explained by dissolution or dilution alone.

One might expect a higher accumulation rate of terrigenous detrital matter at Site 967 during time intervals of high Nile discharge. As shown, this is not the case and even a reduction by $30 \%$ during these time periods did occur. Therefore, we propose that the input of eolian matter must have decreased dramatically during times of enhanced Nile discharge. Ganor and Mamane (1982) estimated that 20-40 million tons of dust annually reach the Eastern Mediterranean. Dispersed over an area of $\sim 1$ million $\mathrm{km}^{2}$ this would result in an accumulation rate of 20 to $40 \mathrm{~g} / \mathrm{m}^{2} \cdot \mathrm{yr}$, which is of the same order of magnitude as the calculated MAR $\left(2.92 \mathrm{~g} / \mathrm{cm}^{2} \cdot \mathrm{k} . \mathrm{y} .=29.2 \mathrm{~g} / \mathrm{m}^{2} \cdot \mathrm{yr}\right)$, and therefore, possibly a gross overestimation. Loÿe-Pilot et al. (1986) computed a mass accumulation of $14 \mathrm{~g} / \mathrm{m}^{2} \cdot \mathrm{yr}$ of Saharan dust in the northwestern Mediterranean. Such enormous amounts of dust, which are presumably transported into the Mediterranean at present, must have a drastic influence on variations of sediment accumulation rates, particularly during more humid climates.

\section{Duration of Sapropel Events}

It is not easy to give an accurate estimate for the duration of a sapropel event, because reliable criteria for the onset and end of such 
events have to be established. A sapropel layer is defined by sedimentological parameters, like color, thickness, and TOC content (Kidd et al., 1978). It is difficult to determine how far diagenetic processes, such as oxidation of organic matter, might have reduced the thickness of the original sapropel. Fe/Al and $\mathrm{Ni} / \mathrm{Al}$ ratios of Site 967 samples give an idea about diagenetic influences. Below sapropel layers, the $\mathrm{Fe}-$ and Ni-contents are elevated, which, according to Passier et al. (1996), is caused by downward migration of $\mathrm{HS}^{-}$and precipitation of sulfides. Upward-migration effects, similar to the ones described by Pruysers et al. (1991) or Thomson et al. (1995), can be seen in the Fe/ $\mathrm{Al}$ or Ni/Al profile of Site 964 (Fig. 3). Based on the thickness of the dark-colored intervals and the sedimentation rates calculated above, values of 1000-4000 yr (Site 964) or 2000-6000 yr (Site 967) are obtained for the duration of a sapropel event.

If $\mathrm{Ba}$ serves as a reliable productivity indicator and if horizons with increased amounts of bio-barite have not been altered too much by diagenesis, we can use the thickness of the Ba spikes to evaluate the duration of periods with enhanced productivity, if sedimentation rates are known. At Site 964 the duration of these productivity events varies between 1000 and 4000 yr. For Site 967, values of 8000$12,000 \mathrm{yr}$ are obtained; here the Ba peaks are wider than the sapropel layers. It must be noted that Ba peaks seem to indicate periods of enhanced productivity, but they do not inevitably indicate the original thickness of a sapropel.

\section{Scenario of Sapropel Formation}

We suggest that the flux of eolian dust simultaneously decreased when Nile discharge and fluvial input from the northern borderlands increased periodically (Fig. 6). When perihelion occurs during the northern hemisphere summer, monsoonal influence on equatorial Africa becomes more intense (Prell and Kutzbach, 1987). Large parts of the Sahara and important draining areas of the Nile (e.g., the Ethiopian highlands) may be under the influence of tropical monsoon rains when the trade-wind zone is shifting northwards, which is the case when sun insolation in the northern hemisphere reaches maximum value (Fairbridge, 1964). Evidence for increased humidity in the Sahara is, for example, given by the occurrence of fossil groundwaters (Sonntag et al., 1980), variations in Saharan vegetation (Lauer and Frankenberg, 1980), and the presence of Pleistocene lakes (PetitMaire et al., 1980). Furthermore, eolian sedimentation of Saharan dust in the Atlantic has also varied periodically (Sarnthein and Koopmann, 1980; Tiedemann et al., 1989). Sediments with the lowest content of Saharan dust coincide with minima in the precessional index.

Monsoon-related increases in Nile discharge, as described by Rossignol-Strick (1983), are documented by sea-level stands in northeast Africa (Rognon and Williams, 1977; Street and Grove, 1979), as well as flood-plain deposits of the Nile (Adamson et al., 1980). Investigations by Rossignol-Strick (1987), Wijmstra et al. (1990), and Rohling and Hilgen (1991) support the idea that the northern borderlands of the Mediterranean went through periods of increased humidity when perihelion occurred in the northern hemisphere summer, and enhanced Mediterranean summer depressions provided higher precipitation rates. Additionally, Jenkins and Williams (1983/84) calculated that Nile discharge alone cannot be high enough to explain the surface-water freshening found by $\delta^{18} \mathrm{O}$ measurements of planktonic foraminifers.

According to our results, sapropel formation seems to depend predominantly on the strength of fluviatile input or, generally speaking, on humidity in the circum-Mediterranean. This would provide the necessary nutrients for the observed productivity increase, and lead to a lower ratio of evaporation vs. runoff, plus precipitation. As we have already shown, Site 967 sapropels were formed at times of high discharge of the Nile River, as seen in the specific terrigenous detrital-matter contributions. When runoff (humidity) and productivity signals $(\mathrm{K} / \mathrm{Al}$ and $\mathrm{Ba} / \mathrm{Al})$ were too weak, sapropels did not form or were easily oxidized during early diagenesis.
At Site 964, sapropel formation does not clearly correspond with changes in detrital matter input. One possible reason might be that sapropel-forming conditions did develop first in the most eastern part of the Eastern Mediterranean in close vicinity to the Nile cone. Subsequently those conditions were established in the deep Ionian basin.

\section{CONCLUSIONS}

The chemical composition of the terrigenous detrital component of Pliocene sediments from the Eastern Mediterranean (Sites 964 and 967) exhibits cyclic changes, which are caused by precessioninduced climatic variations. Periodicity in major element abundances reflects episodes of either enhanced eolian or fluviatile input.

At Site 964 (Pisano Plateau), terrigenous detrital matter chemistry reflects periods of stronger Saharan dust input alternating with fluvial input from the northern borderlands. Site 967 (Eratosthenes Seamount) sediments are strongly influenced by discharge from the Nile River during humid periods (low K/Al ratio).

At Site 967, sapropels are occurring only during periods of enhanced Nile discharge. Accumulation rates of carbonate and terrigenous detrital matter were $30 \%$ lower during such episodes because of the reduction in eolian input and carbonate production and/or dissolution.

Bioproductivity, as calculated from excess Ba concentrations, increased by a factor of up to 5 during time intervals of enhanced freshwater discharge. Not every productivity event is manifested in a sapropel layer.

Based on organic-carbon concentrations, episodes of sapropel formation did at least last from 1000 to $4000 \mathrm{yr}$ at Site 964 and from 2000 to $6000 \mathrm{yr}$ at Site 967 . Periods of enhanced bio-productivity, as defined by Ba enrichments, did last from 8000 to 12,000 yr at Site 967.

\section{ACKNOWLEDGMENTS}

We would like to thank the crew and scientific party of ODP Leg 160 for their generous support. Thanks to B. Schnetger and H. Schale for their help during sample preparation and analysis. A. Eisenhauer kindly provided the preliminary $\mathrm{Sr}$-isotope measurements. The reviews and critical comments of G.-J. De Lange and M. Krom are gratefully acknowledged. This project was financially supported by the German Science Foundation (ODP-SPP).

\section{REFERENCES}

Adamson, D.A., Gasse, F., Street, F.A., and Williams, M.A.J., 1980. Late Quaternary history of the Nile. Nature, 288:50-55.

Bernat, M., Church, T., and Allegre, C.J., 1972. Barium and strontium concentrations in Pacific and Mediterranean sea water by direct isotope dilution mass spectrometry. Earth Planet. Sci. Lett., 16:75-80.

Béthoux, J.-P., 1989. Oxygen consumption, new production, vertical advection and environmental evolution of the Mediterranean Sea. Deep-Sea Res., 36:769-781.

Blechschmidt, G., Cita, M.B., Mazzei, R., and Salvatori, G. 1982. Stratigraphy of the Western Mediterranean and Southern Calabrian Ridges, Eastern Mediterranean. Mar. Micropaleontol., 7:101-134.

Brumsack, H.-J., 1986. The inorganic geochemistry of Cretaceous black shales (DSDP Leg 41) in comparison to modern upwelling sediments from the Gulf of California. In Summerhayes, C.P., and Shackleton, N.J. (Eds.), North Atlantic Palaeoceanography. Geol. Soc. London Spec. Publ., 21:447-462.

Brumsack, H.-J., and Gieskes, J.M., 1983. Interstitial water trace-metal chemistry of laminated sediments from the Gulf of California, Mexico. Mar. Chem., 14:89-106.

Brumsack, H.-J., Zuleger, E., Gohn, E., and Murray, R.W., 1992. Stable and radiogenic isotopes in pore waters from Leg 127, Japan Sea. In Pisciotto, K.A., Ingle, J.C., Jr., von Breymann, M.T., Barron, J., et al., Proc. ODP, 
Sci. Results, 127/128 (Pt. 1): College Station, TX (Ocean Drilling Program), 635-650.

Calvert, S.E., 1983. Geochemistry of Pleistocene sapropels and associated sediments from the Eastern Mediterranean. Oceanol. Acta, 6:225-267.

Chester, R., Baxter, G.G., Behairy, A.K.A., Connor, K., Cross, D., Elderfield, H., and Padgham, R.C., 1977. Soil-sized eolian dusts from the lower troposphere of the Eastern Mediterranean Sea. Mar. Geol., 24:201-217.

Cornille, P., Maenhaut, W., and Pacyna, J.M., 1990. Sources and Characteristics of the atmospheric Aerosol near Damascus, Syria. Atmosph. Environ., 24:1083-1093.

Dehairs, F., Chesselet, R., and Jedwab, J., 1980. Discrete suspended particles of barite and the barium cycle in the open ocean. Earth Planet. Sci. Lett., 49:528-550.

De Visser, J.P., Ebbing, J.H.J., Gudjonsson, L., Hilgen, F.J., Jorissen, F.J., Verhallen, P.J.J.M., and Zevenboom, D., 1989. The origin of rhythmic bedding in the Pliocene Trubi formation of Sicily, southern Italy. Palaeogeogr., Palaeoclimatol., Palaeoecol., 69:45-66.

Dominik, J., and Stoffers, P., 1978. The influence of late Quaternary stagnations on clay sedimentation in the Eastern Mediterranean Sea. Geol. Rundsch., 68:302-317.

Dymond, J., Suess, E., and Lyle, M., 1992. Barium in deep-sea sediment: a geochemical proxy for paleoproductivity. Paleoceanography, 7:163-182.

Emeis, K.-C., Robertson, A.H.F., Richter, C., et al., 1996. Proc. ODP, Init. Repts., 160: College Station, TX (Ocean Drilling Program).

Fairbridge, R.W., 1964. Eiszeitklima in Nordafrika. Geol. Rundsch., 54:399414.

Fischer, A.G., and Bottjer, D.J., 1991. Orbital forcing and sedimentary sequences, introduction. J. Sediment. Petrol., 61:1063-1069.

Foucault, A., and Mélières, F., 1995. Nature et origine des cycles sédimentaires métriques du Pliocène de l’Ouest méditerranéen d'après l'étude du contenu terrigène de la Formation Narbone (Punta Piccola, Sicile, Italie). C. R. Acad. Sci. Paris, 321:869-876.

Ganor, E., and Mamane, Y., 1982. Transport of Saharan dust across the Eastern Mediterranean. Atmosph. Environ., 16:581-587.

Goldberg, E.D., and Arrhenius, G.O.S., 1958. Geochemistry of Pacific pelagic sediments. Geochim. Cosmochim. Acta, 13:153-212.

Higgs, N.C., Thomson, J., Wilson, T.R.S., and Croudace, I.W., 1994. Modification and complete removal of eastern Mediterranean sapropels by postdepositional oxidation. Geology, 22:423-426.

Hilgen, F.J., 1991. Astronomical calibration of Gauss to Matuyama sapropels in the Mediterranean and implication for the geomagnetic polarity time scale. Earth Planet. Sci. Lett., 104:226-244.

Howell, M.W., Rio, D., and Thunell, R.C., 1990. Laminated sediments from the Vrica Section (Calabria, S. Italy): evidence for Plio-Pleistocene climatic change in the Mediterranean region. Palaeogeogr., Palaeoclimatol., Palaeoecol., 78:195-216.

Howell, M.W., and Thunell, R.C., 1992. Organic carbon accumulation in Bannock Basin: evaluating the role of productivity in the formation of Eastern Mediterranean sapropels. Mar. Geol., 103:461-471.

Jenkins, J.A., and Williams, D.F., 1983/84. Nile Water as a cause of Eastern Mediterranean sapropel formation: evidence for and against. Mar. Micropaleontol., 9:521-534.

Kastens, K.A, and Cita, M.B., 1981. Tsunami-induced sediment transport in the abyssal Mediterranean Sea. Geol. Soc. Am. Bull., 92:845-857.

Kidd, R.B., Cita, M.B., and Ryan, W.B.F., 1978. Stratigraphy of eastern Mediterranean sapropel sequences recovered during DSDP Leg 42A and their paleoenvironmental significance. In Hsü, K.J., Montadert, L., et al., Init. Repts. DSDP, 42 (Pt. 1): Washington (U.S. Govt. Printing Office), 421-443.

Krom, M.D., Brenner, S., Kress, N., Neori, A., and Gordon, L.I., 1992. Nutrient dynamics and new production in a warm-core eddy from the Eastern Mediterranean. Deep-Sea Res., 39:467-480.

Langereis, C.G., and Hilgen, F.J., 1991. The Rosello composite: a Mediterranean and global reference section for the early to early-late Pliocene. Earth Planet. Sci. Lett., 104:211-225.

Lauer, W., and Frankenberg, P., 1980. Modelling of climate and plant cover in the Sahara for 5500 B.P. and 18000 B.P. In Sarnthein, M., and Seibold, E. (Eds.), Sahara and Surrounding Seas: Rotterdam (A.A. Balkema), 307-315.

Lea, D.W., and Boyle, A., 1990. Foraminiferal reconstruction of barium distributions in water masses of the glacial oceans. Paleoceanography, 5:719-742.
Lourens, L.J., Hilgen, F.J., Gudjonsson, L., and Zachariasse, W.J., 1992. Late Pliocene to early Pleistocene astronomically forced sea surface productivity and temperature variations in the Mediterranean. Mar. Micropaleontol., 19:49-78.

Loÿe-Pilot, M.D., Martin, J.M., and Morelli, J., 1986. Influence of Saharan dust on the rain acidity and atmospheric input to the Mediterranean. Nature, 321:427-428.

Mangini, A., and Dominik, J., 1979. Late Quaternary sapropel on the Mediterranean Ridge: U-budget and evidence for low sedimentation rates. Sediment. Geol., 23:113-125.

Martin, J.M., and Meybeck, M., 1979. Elemental mass-balance of material carried by major world rivers. Mar. Chem., 7:173-206.

Matthes, S., 1983. Mineralogie: Berlin (Springer Verlag).

Michard, A., Thomson, J., and de Lange, G.-J., 1995. Radiogenic isotopes and sources of S1 sapropel. Terra Nova, 7 (Abstr. suppl. 1):217.

Passier, H.F., Middelburg, J.J., Van Os, B.J.H., and de Lange, G.J., 1996. Diagenetic pyritization under Eastern Mediterranean sapropels caused by downward sulphide diffusion. Geochim. Cosmochim. Acta, 60:751-763.

Petit-Marie, N., Delibrias, G., and Gaven, C., 1980. Pleistocene Lakes in the Shati Area, Fezzan $\left(27^{\circ} 30^{`}\right.$ N). In Sarnthein, M., and Seibold, E. (Eds.), Sahara and the Surrounding Seas: Rotterdam (A.A. Balkema), 289-295.

Prell, W.L., and Kutzbach, J.E., 1987. Monsoon variability over the past 150,000 years. J. Geophys. Res., 92:8411-8425.

Pruysers, P.A., De Lange, G.J., and Middelburg, J.J., 1991. Geochemistry of eastern Mediterranean sediments: primary sediment composition and diagenetic alterations. Mar. Geol., 100:137-154.

Rachold, V., 1991. Spinnweben als Indikatoren für atmosphärisch transportierte natürliche und anthropogene Stäube [Diplomarbeit]. Geochem. Inst., Univ. Göttingen, F.R.G.

Rognon, P., and Williams, M.A.J., 1977. Late Quaternary climatic changes in Australia and North Africa: a preliminary interpretation. Palaeogeogr., Palaeoclimatol., Palaeoecol., 21:285-327.

Rohling, E.J., and Hilgen, F.J., 1991. The eastern Mediterranean climate at times of sapropel formation: a review. Geol. Mijnbouw, 70:253-264.

Rossignol-Strick, M., 1983. African monsoons: an immediate climate response to orbital insolation. Nature, 304:46-49.

- 1985. Mediterranean Quaternary sapropels, an immediate response of the African Monsoon to variation of insolation. Palaeogeogr., Palaeoclimatol., Palaeoecol., 49:237-263.

, 1987. Rainy periods and bottom water stagnation initiating brine accumulation and metal concentrations: 1. Late Quaternary. Paleoceanography, 2:333-360.

Sarnthein, M., Duplessy, J.C., and Fontugne, M.R., 1988. Global variations of surface ocean productivity in low and mid latitudes: influence on $\mathrm{CO}_{2}$ reservoirs of the deep ocean and atmosphere during the last 21,000 years. Paleoceanography, 3:361-399.

Sarnthein, M., and Koopmann, B., 1980. Late Quaternary deep-Sea record on northwest African dust supply and wind circulation. In Sarnthein, M., and Seibold, E. (Eds.), Sahara and the Surrounding Seas: Rotterdam (A.A. Balkema) 239-253.

Schmitz, B., 1987. Barium, equatorial high productivity, and the northward wandering of the Indian continent. Paleoceanography, 2:63-77.

Schnetger, B., 1992. Chemical composition of loess from a local and worldwide view. Neues. Jahrb. Mineral. Monatsh., 1992:29-47.

Sonntag, C., Thorweihe, U., Rudolph, J., Löhnert, E.P., Junghans, C., Münnich, K.O., Klitzsch, E., El Shazly, E.M., and Swailem, F.M., 1980. Isotopic identification of Saharian groundwaters, groundwater formation in the past. In Sarnthein, M., and Seibold, E. (Eds.), Sahara and the Surrounding Seas: Rotterdam (A.A. Balkema), 159-171.

Street, F.A., and Grove, A.T., 1979. Global maps of lake-level fluctuations since 30,000 yr B.P. Quat. Res., 12:83-118.

Ströhle, K.D., Cliff, R.A., Krom, M.D., and Raiswell, R., 1996. Strontium isotope systematics of the Eastern Mediterranean detrital sediment fraction. In Bottrell, S.H., et al. (Eds.), Proc.4th Inter. Symp. on the Geochemistry of the Earth's Surface, Univ. of Leeds, 117-120.

Sutherland, H.E., Calvert, S.E., and Morris, J.R., 1984. Geochemical studies of the recent sapropel and associated sediment from the Hellenic Outer Ridge, eastern Mediterranean Sea, I. Mineralogy and chemical composition. Mar. Geol., 56:79-92.

Thomson, J., Higgs, N.C., Wilson, T.R.S., Croudace, I.W., De Lange, G.J., and Van Santvoort, P.J.M., 1995. Redistribution and geochemical behavior of redox-sensitive elements around S1, the most recent Eastern Mediterranean sapropel. Geochim. Cosmochim. Acta, 59:3487-3501. 
Tiedemann, R., Sarnthein, M., and Stein, R., 1989. Climatic changes in the western Sahara: aeolo-marine sediment record of the last 8 million years (Sites 657-661). In Ruddiman, W., Sarnthein, M., et al., Proc. ODP, Sci. Results, 108: College Station, TX (Ocean Drilling Program), 241-277.

Tomadin, L., Lenaz, R., Landuzzi, V., Mazzucottelli, A., and Vannucci, R., 1984. On wind-blown dusts over the central Mediterranean. Oceanol. Acta, 7:13-24.

Van der Weijden, C.H., 1993. Geochemical signatures preserved in sediments of the Semaforo and Vrica sections (Calabria, Italy) and their relations with variations of the sedimentary regime. Palaeogeogr., Palaeoclimatol., Palaeoecol., 103:203-221.

Van Os, B.J.H., Lourens, L.J., Hilgen, F.J., De Lange, G.J., and Beaufort, L., 1994. The formation of Pliocene sapropels and carbonate cycles in the Mediterranean: diagenesis, dilution, and productivity. Paleoceanography, 9:601-617.

Van Os, B.J.H., Middelburg, J.J., and De Lange, G.J., 1991. Possible diagenetic mobilisation of barium in sapropelic sediment from the Eastern Mediterranean. Mar. Geol., 100:125-136.

Venkatarathnam, K., and Ryan, B.F., 1971. Dispersal patterns of clay minerals in the sediments of the eastern Mediterranean Sea. Mar. Geol., 11:261-282.

Vergnaud-Grazzini, C., Devaux, M., and Znaidi, J., 1986. Stable isotope "anomalies" in Mediterranean Pleistocene records. Mar. Micropaleontol., 10:35-69.

Wedepohl, K.H., 1967. Geochemie: Berlin (de Gruyter, Sammlung Göschen).
, 1971. Environmental influences on the chemical composition of shales and clays. In Ahrens, L.H., Press, F., Runcorn, S.K., and Urey, H.C. (Eds.), Physics and Chemistry of the Earth: Oxford (Pergamon), 307-331.

, 1991. The composition of the upper earth's crust and the natural cycles of selected metals: metals in natural raw materials; natural resources. In Merian, E. (Ed.), Metals and their Compounds in the Natural Environment: Weinheim (VCH-Verlagsges.), 3-17.

Wijmstra, T.A., Young, R., and Witte, H.J.L., 1990. An evaluation of the climatic conditions during the Late Quaternary in northern Greece by means of multivariate analysis of palynological data and comparison with recent phytosociological and climatic data. Geol. Mijnbouw, 69:243-251.

Williams, D.F., and Thunell, R.C., 1979. Faunal and oxygen isotopic evidence for surface water salinity changes during sapropel formation in the eastern Mediterranean. Sediment. Geol., 23:81-93.

Date of initial receipt: 17 January 1997

Date of acceptance: 22 June 1997

Ms 160SR-004 